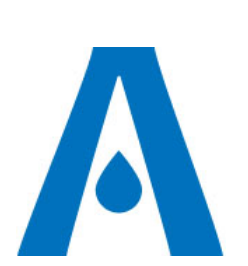

Produced by the AquacultureHub non-profit Foundation the $I J A$ is an open-access, scientific journal, published on http://www.aquaculturehub.org/group/israelijournalofaq uaculturebamidgehija

To read papers free of charge, please register online at the above website Sale of IJA papers is strictly forbidden

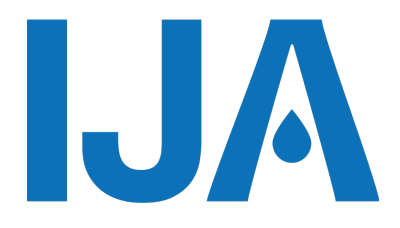

\title{
Effect of Algae Decaying on Shrimp Culture System and Suggested Biological Remediation Strategies
}

\section{Xu-zheng Liao ${ }^{1}$, Jia-zhao Li ${ }^{1}$, Bo Wang1, Hai-peng Qin ${ }^{1}$, Shi-kang $\mathrm{Hu}^{1}$, Ji-chen Zhao ${ }^{1}$, Zi-hao He ${ }^{1}$, Xie-yan Chen ${ }^{1}$, Shi-Ping Yang ${ }^{1,3,4,5 *}$, Cheng-Bo Sun ${ }^{1,2,3,4,5 *}$}

${ }^{1}$ College of Fisheries, Guangdong Ocean University, Zhanjiang, P. R. China

2 Southern Marine Science and Engineering Guangdong Laboratory, Zhanjiang, P. R. China

${ }^{3}$ Guangdong Provincial Key Laboratory of Pathogenic Biology and Epidemiology for Aquatic Economic Animals, Zhanjiang, P. R. China

${ }^{4}$ Guangdong Key Laboratory of Control for Diseases of Aquatic Economic Animals, Zhanjiang, P. R. China

${ }^{5}$ Guangdong Key Laboratory of Control for Diseases of Aquatic Economic Animals, Zhanjiang, P. R. China

Key words: Alga, Decaying, Shrimp, Water quality, Remediation

\begin{abstract}
Pond water with algae blooms was collected, and maintained in the dark over a 2-day period without nutritional supplements. The physico-chemical parameters and the density of algae were measured. The concentration of $\mathrm{NH}$ $4^{+}-\mathrm{N}, \mathrm{DIN}$ and $\mathrm{PO}_{4}^{-}-\mathrm{P}$ in water in darkness significantly increased, and the density of algae decreased significantly. Isolated water was exposed to three bio-remediation water treatments: addition of green algae, Bacillus subtilis and photosynthetic bacteria. After remediation, the concentrations of $\mathrm{NH}_{4}^{+}-\mathrm{N}, \mathrm{NO}_{3}^{-}$ $-\mathrm{N}$, DIN and $\mathrm{PO}_{4}^{-}-\mathrm{P}$ in the three treatment groups were significantly lower than the control group. No difference was observed in the concentration of $\mathrm{NO}_{2}^{-}-\mathrm{N}$ between the control group and the photosynthetic bacteria group. Results from all treatments showed water quality deterioration along with increase in nitrogen and phosphorus concentrations. Bio-remediation methods can be effectively adapted in shrimp culture after algae decay, and one of the most promising biological remediation strategies is the use of green algae.
\end{abstract}




\section{Introduction}

Intensive culture of shrimp is widely practiced in China. In some super intensive white shrimp culture systems, production of over $20000-100000 \mathrm{~kg} / \mathrm{ha}$ can be achieved (Miandare al., 2016; Verdegem et al., 2006). Open systems with high water exchange have been used in traditional shrimp culture. However, in intensive and super intensive shrimp culture systems, closed or recirculating seawater systems with zero or nearly zero water discharges are used. Therefore, for shrimp producers, one of the most difficult challenges is maintaining a stable relationship among the water, shrimp, and microscopic flora and fauna in their pond systems. Farmers try to maintain a rich bloom of green algae $(500,000$ to $2,000,000 \mathrm{cells} / \mathrm{ml})$ in each pond (Lightner et al., 1984). Unfortunately, the lack of water exchange produces a big management problem, i.e., over-blooming algae that eventually die in mass. The dead algae cause a significant increase in ammonia in the water, a decrease in dissolved oxygen and a rise in organic material (Funge-Smith and Briggs, 1998). Gao et al. reported significant increase in colloidal phosphorus, organic carbon, particulate phosphorus and nitrogen over the course of cyanobacteria die off and the decomposition processes (Gao et al., 2013). Ammonia can be transformed to nitrite by ammonia oxidizing bacteria (Hooper et al., 1997). Both ammonia and nitrite are toxic to commercially aquatic animal (Lin and Chen, 2001; Lin and Chen, 2003).

Traditionally, pond aquaculture uses photoautotrophic algae-based green water systems to control inorganic nitrogen (Ebeling and Timmons, 2008). Spirulina platensis was co-cultured with Penaeus monodon, and the results show that $S$. platensis reduced inorganic nitrogen and resulted in excellent water quality for shrimp (Chuntapa et al., 2003). In several studies, water quality was improved with addition of probiotics. Commercial probiotics (contain Bacillus sp., photosynthetic bacteria, Saccharomyces cerevisiae and as well as other) was added into Penaeus vannamei ponds. In treated ponds, dissolved oxygen was significantly higher and dissolved reactive-phosphorus, total inorganic nitrogen and chemical oxygen demand were significantly lower $(P<0.05)$ compared with control ponds (Wang, Y. B. et al., 2005). Bacillus sp. was applied regularly in a modified extensive shrimp ( $P$. monodon) culture pond. Water quality was improved, and optimum transparency and low organic load were maintained in the experimental pond compared with the control group (Dalmin et al., 2001). Addition of Streptomyces as probiotics in $P$. monodon culture tanks also may help maintaining water quality, thereby improving survival and growth (Das et al., 2006). Piamsak et al. (2001) designed a shrimp broodstock, recirculating seawater system with a denitrification component. Including denitrifying bacteria resulted in enhanced removal of nitrate.

The purpose of this study was to evaluate the effect of algae growth and decay on the water quality in a small experimental tank system and the effect of using different microorganisms to repair water quality. This study could strengthen guidance on water quality management and provide methods for microorganisms to improve water quality in shrimp culture.

\section{Algae cultures}

\section{Materials and Methods}

Bacillu. subtilis (Zhanjiang Haike biotechnology co., LTD) and photosynthetic bacteria (Jangsu Luke biotechnology co., LTD) products were obtained directly from the manufacturers. The preparation and application of the products were carried out according to the manufacturer's instructions. The green alga, Chlorella pyrenoidosa, was cultured in laboratory under natural conditions. When cultures reached the mid-logarithmic growth phase, alga cells were collected by centrifugation at $4000 \times \mathrm{g}$ for $10 \mathrm{~min}$ at $4^{\circ} \mathrm{C}$ and washed with seawater, then added to shrimp culture tanks.

\section{Shrimp rearing and experimental conditions}

The experiments were carried out in a shrimp farm located at Shanya, Hainan. A batch of apparently healthy $P$. vannamei (mean body length of $4.15 \pm 1.12 \mathrm{~cm}$ ) were collected directly from the shrimp pond. The shrimps were transferred to twelve plastic tanks $(0.3$ $\mathrm{m}^{3}$ ) filled with pond water at a density of 30 shrimps per tank. Each tank was ventilated 
by four air stones, and freshwater was added daily to maintain a constant salinity. Feces, uneaten feed and dead shrimp were removed daily by siphon, and water was returned to the same tank. Shrimps in each tank were fed three times daily with commercial shrimp feed ( $35 \%$ crude protein) at about $4 \%$ of body weight.

\section{Design of the experiment}

Pond water with algae blooms characterize the algal density and the dominant species composition was collected and transferred to twelve plastic tanks. All 12 tanks were maintained in darkness over a 2-day period. Keeping the algae without nutritional supplements from the sediment or external sources would deposit and decay. The physicochemical parameters in each tank, including $\mathrm{NH}_{4}{ }^{+}-\mathrm{N}, \mathrm{NO}_{2}^{-}-\mathrm{N}, \mathrm{NO}_{3}^{-}-\mathrm{N}, \mathrm{PO}_{4}^{-} \mathrm{P}$, and DIN, would be measured at the beginning and end of the experiment. The number of alga cells were counted using a hemocytometer with light microscope.

Following the darkness exposure, all 12 tanks were transferred into area exposed to natural light conditions. Tanks were divided into three treatment groups and one control group, with three replicates per treatment: shrimp cultured with $C$. pyrenoidosa (the algae group), shrimp cultured with photosynthetic bacteria (the PSB group) and shrimp cultured with $B$. subtilis (the bacillus group). The treatment without microorganism added was regarded as a control group. The physicochemical parameters in each tank were measured daily. The treatment lasted 6 days. The concentration of $C$. pyrenoidosa added to each tank was $10^{6} \mathrm{cell} / \mathrm{ml}$. Similarly, the concentration of Photosynthetic bacteria and B. subtilis added to each tank was $10^{6} \mathrm{CFU} / \mathrm{ml}$.

\section{Sample storage and measurement methods}

Total ammonia-nitrogen $\left(\mathrm{NH}_{4}^{+}-\mathrm{N}\right)$, nitrite-nitrogen $\left(\mathrm{NO}_{2}^{-}-\mathrm{N}\right)$, nitrate-nitrogen $\left(\mathrm{NO}_{3}^{-}-\mathrm{N}\right)$ and dissolved reactive-phosphorus $\left(\mathrm{PO}_{4}^{-}-\mathrm{P}\right)$ were measured according to 'Standard methods for the examination of water and Wastewater'. Each sample for chemical parameters was filtered through pre-combusted glass fiber filters. The sum of $\mathrm{NH}_{4}{ }^{+}-\mathrm{N}, \mathrm{NO}_{2}-\mathrm{N}$, and $\mathrm{NO}_{3}{ }^{-}-\mathrm{N}$, referred to as dissolved inorganic nitrogen (DIN), was calculated. Temperature, $\mathrm{pH}$, and salinity were also monitored.

Water samples $(500 \mathrm{~mL})$ from each tank were fixed with Lugol's iodine solution $(5 \mathrm{~mL})$. The lower layer $(50 \mathrm{~mL})$ containing the algal sediment was counted using a light microscope.

\section{Calculations and statistical analyses}

Data collected was analyzed using SPSS version 13 (SPSS, American). Differences in mean values of water quality and algal populations were established using one-way Analysis of Variance (ANOVA). All data are expressed as means \pm SD.

\section{Results}

Physicochemical parameters of darkness experiment

Physicochemical parameters of water before and after the experiment are shown in Table 1. Algae in the darkened tanks began to die and decompose, and various nutrition substances were released. Before the darkness exposure, the various physico-chemical parameters of the experimental water were at a low level. Darkness exposure significantly reduced algal density with significant increase in the $\mathrm{NH}_{4}{ }^{+}-\mathrm{N}$, DIN, and $\mathrm{PO}_{4}^{-}-\mathrm{P}$ by $501 \%$, $405 \%$, and $2282 \%$, respectively.

\section{Physicochemical parameters of breeding experiment}

The variation of $\mathrm{NH}_{4}{ }^{+}-\mathrm{N}$ in the experimental water during the remediation process is shown in Figure 1a. The concentration of $\mathrm{NH}_{4}^{+}-\mathrm{N}$ in the control group increased constantly, while in the treated groups it increased during 2-3 days remaining at that level (bacillus group) or decreasing constantly (algae and PSB groups) afterwards. At the end of the experiment, the concentration of $\mathrm{NH}_{4}{ }^{+}-\mathrm{N}$ in the three treatment groups were significantly lower than that in the control group with a final removal rate of $25 \%$ in the algae group and $40 \%$ the PSB group (Figure 1a). 
Liao et al.

Table 1 Physico-chemical parameters of water before and after darkness treatment.

\begin{tabular}{lllll}
\hline & Initial value & Final value & Increase value & $\begin{array}{l}\text { Percent increase } \\
\text { value (\%) }\end{array}$ \\
\hline $\begin{array}{l}\mathrm{NH}_{4}{ }^{+}-\mathrm{N}(\mathrm{mg}) \\
\mathrm{NO}^{-}-\mathrm{N} \\
(\mathrm{mg} / \mathrm{L})\end{array}$ & $0.093 \pm 0.0037^{\mathrm{a}}$ & $0.559 \pm 0.1228^{\mathrm{b}}$ & 0.466 & 501 \\
$\mathrm{NO}_{3}{ }^{-}-\mathrm{N}$ & $0.055 \pm 0.0201^{\mathrm{a}}$ & $0.199 \pm 0.0789^{\mathrm{b}}$ & 0.144 & 200 \\
$(\mathrm{mg} / \mathrm{L})$ & $0.0003^{\mathrm{a}}$ & $0.015 \pm 0.0066^{\mathrm{a}}$ & 0.010 & 261 \\
$\begin{array}{l}\mathrm{DIN}(\mathrm{mg} / \mathrm{L}) \\
\mathrm{PO}\end{array}{ }^{-}-\mathrm{P}$ & $0.023 \pm 0.0135^{\mathrm{a}}$ & $0.548 \pm 0.0201^{\mathrm{b}}$ & 0.525 & 405 \\
$(\mathrm{mg} / \mathrm{L})$ & & & & 2282 \\
$\begin{array}{l}\text { Algae }(\log 10 \\
\text { cell/L) }\end{array}$ & $6.038 \pm 0.040^{\mathrm{a}}$ & $5.011 \pm 0.069^{\mathrm{b}}$ & -1.028 & - \\
\hline
\end{tabular}

b
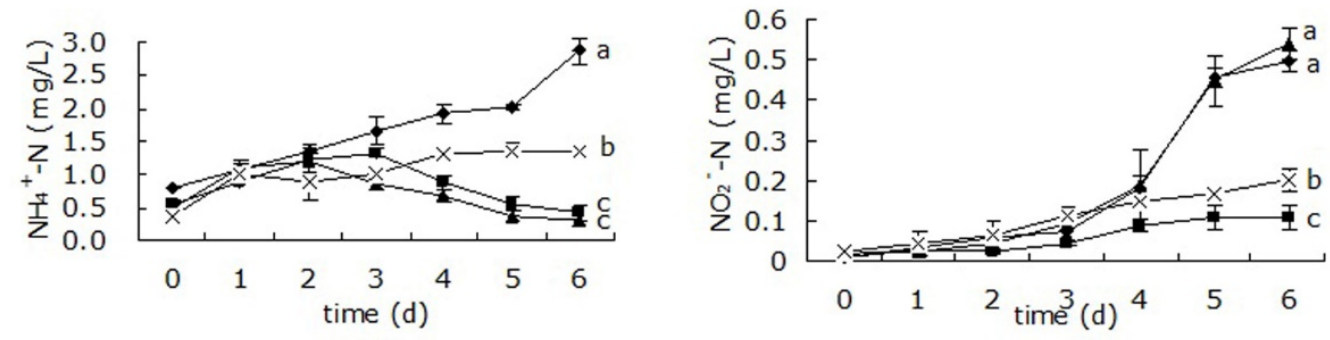

c

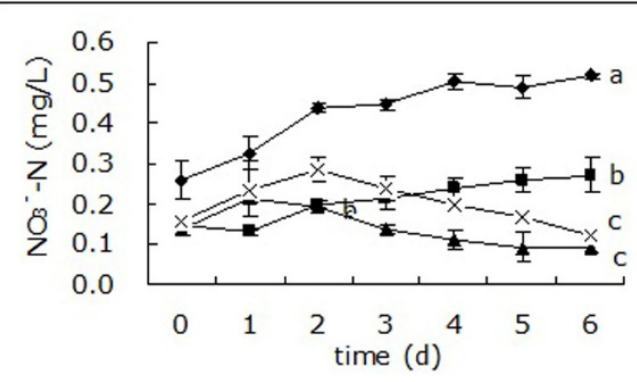

d

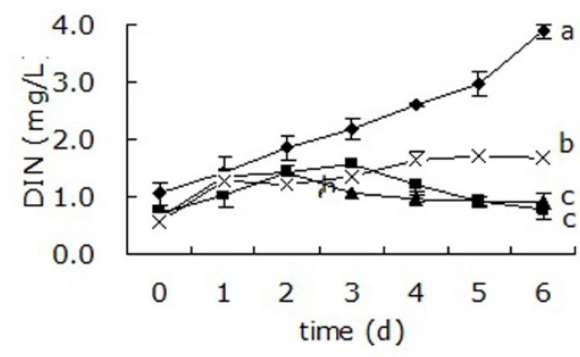

e

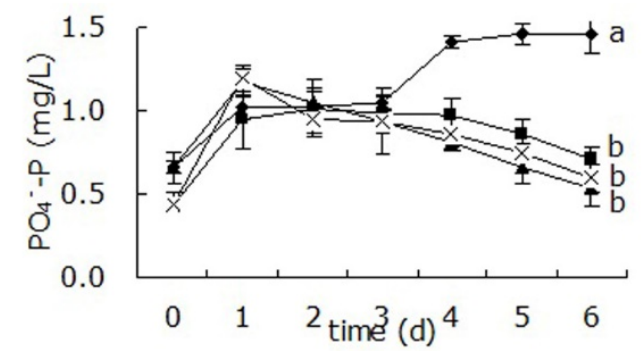

Figure. 1 The concentrations of $\mathrm{NH}_{4}{ }^{+}-\mathrm{N}(\mathrm{a}), \mathrm{NO}_{2}-\mathrm{N}(\mathrm{b}), \mathrm{NO}_{3}-\mathrm{N}(\mathrm{c}), \mathrm{DIN}$ (d) and $\mathrm{PO}_{4}-\mathrm{P}(\mathrm{e})$ during breeding experiment. Different lower-case letters above bars indicate significant differences on that day $(p<0.05)$. $\diamond$ control, $\mathbf{\square}$ =algae, $\boldsymbol{\Delta}=\mathrm{PSB}, x=$ bacillus. 
The variation of $\mathrm{NO}_{2}^{-}-\mathrm{N}$ in the experimental water is shown in Figure $1 \mathrm{~b}$. The concentrations of $\mathrm{NO}_{2}-\mathrm{N}$ in all groups increased constantly. However, at the end of experiment, the concentration of $\mathrm{NO}_{2}{ }^{-}-\mathrm{N}$ in algae and the bacillus treatments were significantly lower than the control (Figure 1b).

The concentration of $\mathrm{NO}_{3}^{-}-\mathrm{N}$ in the control and the algae treatments increased constantly, while those in the PSB group and the bacillus group during 1-2 days to their highest level and then fell. At the end of the experiment, the concentrations of $\mathrm{NO}_{3}^{-}-\mathrm{N}$ in the three treatment groups were significantly lower than that in the control group with a final removal rate of $32 \%$ in the PSB group and $23 \%$ in the bacillus group (Figure 1c).

The concentration of DIN in the control group increased constantly, while those in the algae group and the PSB group increased during 3-4 days to their highest level and then fell. At the end of the experiment, the concentrations of DIN in the three treatment groups were significantly lower than that in the control group (Figure 1d).

During the first day of the experiment the concentration of $\mathrm{PO}_{4}^{-}-\mathrm{P}$ in all groups increased. Afterwards it decreased steadily in all treatments, while in the control it increased from the third day on. At the end of the experiment the concentrations of $\mathrm{PO}_{4}-$ $P$ in all treatment groups were significantly lower than that in the control (Figure 1e), with final removal rates of $20 \%$ in the PSB group and a little less in the other treatments.

\section{Discussion}

In intensive shrimp culture systems, high phytoplankton concentrations are frequently observed because of nutrients from feed addition and shrimp excretion. Shrimp farmers try to maintain phytoplankton concentrations within a certain range in each pond (Lightner et al., 1984). Studies have shown that the use of ammonia nitrogen by phytoplankton is preferred over the use of nitrate (Glibert et al., 2016). Algae normally have a life span of 1-2 weeks, followed by a die off and release of nitrogen species into the water. In this study, algae decaying was promoted via darkness exposure of the water with no supplementation of nutrients. During the darkness exposure algae began to die and decompose which resulted in the release of various nutrition substances. The concentrations of $\mathrm{NH}_{4}{ }^{-}-\mathrm{N}$, DIN, and $\mathrm{PO}_{4}^{-}-\mathrm{P}$ increased significantly, while the algal density decreased significantly. A similar phenomena was described by John and Falkowski (1998) with Dunaliella tertiolecta which underwent catastrophic cell death after about 6 days of darkness which was accompanied by a large increase in protease activity. The induction of a specific protease was considered as the reason for cell death. Bidle and Falkowski (2004) reported that massive algae cell (Microcystis aeruginosa) died after $48 \mathrm{~h}$ treatment under darkness and $\mathrm{O}_{2}$ limitation. When healthy cells were incubated in darkness, morphological characteristics of cell, including migration of chromatin to the outer part of the nuclear membrane, degradation and lysis of nuclear DNA and other internal organelles were detectable in transmission electron micrographs (TEM). Gao et al. (2013) documented significant increase in colloidal phosphorus, nitrogen, organic carbon, particulate phosphorus, and nitrogen during the die off and decomposition of cyanobacteria. Chuai et al. (2011) documented high dissolved phosphorus following a die off and decomposition of cyanobacteria bloom. During the cultivation of cyanobacteria in darkness, the death of a large number of algae led to a decrease in dissolved oxygen in the water, and the concentration of ammonium and phosphate in the water increased greatly, indicating that the changes in nutrients are related to the decrease of dissolved oxygen (Zhu et al., 2011). Anaerobic decomposition of cyanobacterial blooms in Lake Taihu caused a sharp increase in total phosphorus, total nitrogen, and ammonium (Ma et al., 2013). Several researchers also documented that nitrogen $(N)$ and phosphorus $(P)$ are the two main pollutants in effluent water from intensive aquaculture (Gilles et al., 1998; Sidik et al., 2008).

Algae are being used in many aquaculture operations. Although their main applications are related to nutrition, they are also been used for stabilizing and controlling pond water quality. Ebeling and Timmons (2008) documented Spirulina platensis was used for controlling water quality, and results show that $S$. platensis reduced inorganic nitrogen and resulted in excellent water quality for shrimp. Our study indicates a possibility for introducing algae for improve water quality. Our findings clearly show that algae prevent 
the deterioration of water quality led by algae death. Algae removed inorganic nitrogen and dissolved reactive phosphorus, and resulted in relative excellent water quality for shrimp. Balode et al. (1998) added different nutrients from seawater and found that the concentrations of $\mathrm{NH}_{4}^{+}-\mathrm{N}, \mathrm{NO}_{2}^{-}-\mathrm{N}, \mathrm{NO}_{3}^{-}-\mathrm{N}$, DIN and $\mathrm{PO}_{4}^{-}-\mathrm{P}$ in the algae treatment group gradually decreased.

The findings of this study showed that the use of probiotics in the experimental tank system decreased the water rate and helped remove inorganic nitrogen and dissolved reactive phosphorus. This may be due to the different microbial composition to reduce the content of nitrogen and phosphorus in the water. The data suggest that Although the level of some water quality parameters in probiotic treatments also increased, the data suggest that the probiotics enhanced the number of beneficial microbial communities in these treatments. It is most likely that these microbial communities helped to decompose organic matter and to reduce the nitrogen and phosphorus concentrations compared to the control group. Although most bacteria assimilate nitrogen in the form of $\mathrm{NH}_{4}{ }^{+}$to use in biosynthetic pathways, nitrogen removal is classically predominated by autotrophic bacteria in natural systems. Most strains of the photosynthetic bacteria isolated from photosynthetic sludge reactors are capable of using nitrate as the terminal electron acceptor (Hiraishi et al., 1991). Photosynthetic bacteria can utilize nitrate as a nitrogen source (Idi et al., 2015; Nagatani et al., 1971). There have been several reports suggesting a contribution by Bacillus. Bacillus is able to utilize ammonia, nitrate or nitrite as a nitrogen source (Gerard et al., 1989; Nakano et al., 1998). After applying Bacillus sp. in shrimp culture pond, water quality improved (Davis et al., 2008; Wang et al., 2005). Three natural isolates (Bacillus) were obtained from mud sediment, and were capable of decreasing ammonium, nitrite, nitrate and phosphate ions (Lalloo et al., 2010).

\section{Acknowledgements}

This work was supported by the Project of 2019 Annual Guangdong Provincial Special Financial Fund (No. 2319412525), Fangchenggang Science and Technology Plan Project (No. AD19008017) and Guangdong Province Laboratory Independent Project (No. ZJW2019-07). We also thank all the people who have dedicated their time to these experiments.

\section{References}

Balode, M., Purina, I., Beéchemin, C., \& Maestrini, S. Y., 1998. Effects of nutrient enrichment on the growth rates and community structure of summer phytoplankton from the Gulf of Riga, Baltic Sea, 45(279): 1365-1371.

Bidle, K. D., \& Falkowski, P. G., 2004. Cell death in planktonic, photosynthetic microorganisms. Nature Reviews Microbiology, 2(8): 643-655.

Chuai, X. M., Ding, W., Chen, X. F., Wang, X. L., Miao, A. J., Xi, B. D., He, L. S., \& Yang, L. Y., 2011. Phosphorus release from cyanobacterial blooms in Meiliang Bay of Lake Taihu, China. Ecological Engineering, 37(6): 842-849.

Chuntapa, B., Powtongsook, S., \& Menasveta, P., 2003. Water quality control using Spirulina platensis in shrimp culture tanks. Aquaculture, 220(1-4): 355-366.

Dalmin, G., Kathiresan, K., \& Purushothaman, A., 2001. Effect of probiotics on bacterial population and health status of shrimp in culture pond ecosystem. Indian Journal of Experimental Biology, 39(9): 939-942.

Das, S., Lyla, P. S., \& Khan, S. A., 2006. Application of streptomyces as a probiotic in the laboratory culture of Penaeus monodon (Fabricius). Israeli Journal of AquacultureBamidgeh, 58(3): 198-204.

Davis, M. E., Parrott, T., Brown, D. C., de Rodas, B. Z., Johnson, Z. B., Maxwell, C. V., \& Rehberger, T., 2008. Effect of a Bacillus-based direct-fed microbial feed supplement on growth performance and pen cleaning characteristics of growing-finishing pigs. Journal of Animal Science, 86(6): 1459-1467.

Funge-Smith, S. J., \& Briggs, M. R. P., 1998. Nutrient budgets in intensive shrimp ponds: implications for sustainability. Aquaculture, 164(1-4): 117-133. 
Gao, L. I., Zhang, L., Hou, J., Quan, W., Feng, F. U., \& Shao, H., 2013. Decomposition of macroalgal blooms influences phosphorus release from the sediments and implications for coastal restoration in Swan Lake, Shandong, China. Ecological Engineering, 60(6): 1928.

Denariaz, G., Payne, W. J., \& Gall, J. L., 1989. A Halophilic Denitrifier, Bacillus halodenitrificans sp. nov. International journal of systematic bacteriology, 39(2): 145-151. Gilles, L., Jean-Louis, M., Gilbert, D., \& Cécile, G., 1998. Nitrogen and phosphorus waste production in a flow-through land-based farm of European seabass (Dicentrarchus labrax). Aquatic Living Resources, 11(4): 247-254.

Glibert, P. M., Wilkerson, F. P., Dugdale, R. C., Raven, J. A., Dupont, C. L., Leavitt, P. R., Parker, A. E., Burkholder, J. M., \& Kana, T. M., 2016. Pluses and minuses of ammonium and nitrate uptake and assimilation by phytoplankton and implications for productivity and community composition, with emphasis on nitrogen-enriched conditions. Limnology and Oceanography, 61(1): 165-197.

Hiraishi, A., Morishima, Y., \& Kitamura, H., 1991. Use of isoprenoid quinone profiles to study the bacterial community structure and population dynamics in the photosynthetic sludge system. Technology, 23(4-6): 937-945.

Hooper, A. B., Vannelli, T., Bergmann, D. J., \& Arciero, D. M., 1997. Enzymology of the oxidation of ammonia to nitrite by bacteria. Antonie van Leeuwenhoek, 71(1-2): 5967.

Idi, A., Nor, M. H. M., Wahab, M. F. A., \& Ibrahim, Z., 2015. Photosynthetic bacteria: an eco-friendly and cheap tool for bioremediation. Reviews in Environmental Science and Bio-Technology, 14(2): 271-285.

Ebeling, J.M., \& Timmons, M. B., 2008. Carbon: nitrogen balance impacts nitrogen removal processes in microbial-based aquaculture systems. Glob. Aquac. Advo., 11: 3840.

John, A. B., \& Falkowski, P. G., 1998. Physiological stress and cell death in marine phytoplankton: induction of proteases in response to nitrogen or light limitation. Limnology and Oceanography, 43(1): 129-135.

Lalloo, R., Ramchuran, S., Ramduth, D., Görgens, J., \& Gardiner, N., 2010. Isolation and selection of Bacillus spp. as potential biological agents for enhancement of water quality in culture of ornamental fish. Journal of Applied Microbiology, 103(5): 1471-1479.

Lightner, D.V., Redman, R.M., Danald, D.A., Williams, R.R., \& Perez, L. A., 1984. Major diseases encountered in controlled environment culture of penaeid shrimp at Puerto Penasco, Sonora, Mexico. In Tenth US-Japan Meetings on Aquaculture: 25.

Lin, Y. C., \& Chen, J. C., 2001. Acute toxicity of ammonia on Litopenaeus vannamei Boone juveniles at different salinity levels. Journal of Experimental Marine Biology and Ecology, 259(1): 109-119.

Lin, Y. C., \& Chen, J. C., 2003. Acute toxicity of nitrite on Litopenaeus vannamei (Boone) juveniles at different salinity levels. Aquaculture, 224(1-4): 193-201.

Ma, Z. M., Niu, Y., Xie, P., Chen, J., Tao, M., \& Deng, X. W., 2013. Off-flavor compounds from decaying cyanobacterial blooms of Lake Taihu. Journal of Environmental Sciences-China, 25(3): 495-501.

Miandare, H. K., Yarahmadi, P., \& Abbasian, M., 2016. Immune related transcriptional responses and performance of Litopenaeus vannamei post-larvae fed on dietary probiotic PrimaLac (R). Fish \& Shellfish Immunology, 55: 671-678.

Nagatani, H., Shimizu, M., \& Valentine, R. C., 1971. The mechanism of ammonia assimilation in nitrogen fixing bacteria. Archiv für Mikrobiologie, 79(2): 164-175.

Nakano, M. M., Hoffmann, T., Zhu, Y., \& Jahn, D., 1998. Nitrogen and oxygen regulation of Bacillus subtilis nasDEF encoding NADH-dependent nitrite reductase by TnrA and ResDE. Journal of Bacteriology, 180(20): 5344-5350.

Piamsak, M., Tanya, P., Pakitsin, S., Sorawit, P., Benjamas, C., \& Phillip, L., 2001. Design and function of a closed, recirculating seawater system with denitrification for the culture of black tiger shrimp broodstock. Aquacultural Engineering, 25: 35-49. 
Sidik, M. J., Rashed-Un-Nabi, M., \& Hoque, M. A., 2008. Distribution of phytoplankton community in relation to environmental parameters in cage culture area of Sepanggar Bay, Sabah, Malaysia. Estuarine Coastal and Shelf Science, 80(2): 251-260.

Verdegem, M. C. J., Bosma, R. H., \& Verreth, J. A. J., 2006. Reducing water use for animal production through aquaculture. International Journal of Water Resources Development, 22(1): 101-113.

Wang, Y. B., Xu, Z. R., \& Xia, M. S., 2005. The effectiveness of commercial probiotics in northern white shrimp Penaeus vannamei ponds. Fisheries Science, 71(5): 1036-1041. Zhu, M. Y., Zhu, G. W., \& Wang, Y. P., 2011. Influence of Scum of Algal Bloom on the Release of N and P from Sediments of Lake Taihu. Environmental Science, 32(2): 409. 